\title{
Thrombin Generation Capacity of Methylene Blue-Treated Plasma Prepared by the Theraflex MB Plasma System
}

\author{
Ute Gravemann ${ }^{\mathrm{a}} \quad$ Manuela Kusch $^{\mathrm{b}}$ Herbert Koenig ${ }^{\mathrm{b}}$ Harald Mohr ${ }^{\mathrm{a}}$ Thomas H. Mueller ${ }^{\mathrm{a}}$ \\ ${ }^{a}$ DRK-Blutspendedienst NSTOB, Institut Springe, \\ ${ }^{b}$ Division of Hematology and Transfusion Medicine, Paul Ehrlich Institute, Langen, Germany
}

\section{Key Words}

Thrombin generation capacity $\cdot$ MB plasma .

Theraflex MB plasma system

\section{Summary}

Background: Methylene blue (MB) / light treatment is a wellknown procedure for the inactivation of pathogens in fresh frozen plasma (FFP). Aim of the current study was to investigate the thrombin generation (TG) characteristics and quality of MB plasma prepared by the Theraflex MB Plasma System. Methods: Single donor plasma units $(n=18)$ were MB/lighttreated, with sampling before and after processing. Preparation included leukocyte depletion, addition of MB pill prior to illumination, and depletion of $\mathrm{MB}$ and photoproducts by filtration. Different plasma parameters and TG were measured. TG additionally was determined in solvent/detergent plasma $(\mathrm{n}=8$ ). Results: MB/light treatment significantly affected factors $\mathrm{V}, \mathrm{VIII}$ and $\mathrm{XI}$, which were decreased by $9-18 \%$. While the antigen level was not affected, fibrinogen according to Clauss was decreased by $7 \%$, correlating with a $12 \%$ prolongation of TT and RT. The total amount of free thrombin generated, given as 'area under the curve' (AUC), was comparable for untreated ( $93 \pm 18 \%$ of normal plasma) and MB/light-treated plasma $(95 \pm 20 \%)$. Also peak thrombin concentration was not significantly affected by treatment $(94 \pm 11 \%$ (untreated) vs. $96 \pm 12 \%$ (treated)). The 'time to peak' value (TTP) was $105 \%$ of normal plasma for untreated FFP and $89 \%$ for MBtreated plasma. Conclusion: For plasma treated with the Theraflex MB Plasma System no profound influence of MB/ light treatment on the characteristics of thrombin generation was detected. In concordance with data from the literature, coagulation factors $\mathrm{V}, \mathrm{VIII}$ and $\mathrm{XI}$ were decreased due to $\mathrm{MB} /$ light treatment. Decrease was less than $20 \%$.

\section{Schlüsselwörter}

Thrombinbildungskapazität · MB-Plasma .

Theraflex MB Plasma System

\section{Zusammenfassung}

Hintergrund: Die Methylenblau(MB)/Licht-Behandlung ist eine etablierte Methode zur Pathogeninaktivierung von gefrorenem Frischplasma (GFP). Ziel der vorliegenden Studie war die Ermittlung der Thrombinbildungs-Charakteristika und der Qualität von MB-Plasma, das mit dem Theraflex MB Plasma System herstellt wurde. Methoden: Es wurden 18 Einzelspenderpräparate mit MB/Licht behandelt und Proben vor und nach Behandlung genommen. Die Herstellung umfasste die Leukozytendepletion, die Zugabe von MB (als Tablette), die Belichtung sowie die anschließende Entfernung von MB und seinen Photoprodukten. Verschiedene Plasmaparameter sowie die Thrombinbildung wurden gemessen. Die Thrombinbildung wurde darüber hinaus auch für Solvent/DetergentPlasma $(n=8)$ untersucht. Ergebnisse: MB/Licht-Behandlung führte zu einer signifikanten Abnahme der Faktoren V, VIII und $\mathrm{XI}$ um 9-18\%. Das Fibrinogen nach Clauss nahm um 7\% ab, wohingegen die Antigenkonzentration nicht beeinflusst wurde. Die Abnahme der Fibrinogenaktivität korrelierte mit einer um $12 \%$ verlängerten Thrombin- und Reptilasezeit. Die Gesamtmenge des im Thrombinbildungs-Assay nachgewiesenen freien Thrombins, angegeben als "area under the curve" (AUC), war vergleichbar für unbehandeltes (93 $\pm 18 \%$ bezogen auf Normalplasma) und MB/Licht-behandeltes Plasma $(95 \pm 20 \%)$. Auch die Peak-Thrombinkonzentration wurde durch die Behandlung nicht signifikant beeinflusst ( $94 \pm 11 \%$ (unbehandelt) versus $96 \pm 12 \%$ (behandelt). Die Zeit bis zum Erreichen des Peaks («time to peak» (TTP)) betrug für unbehandeltes GFP 105\% verglichen mit Normalplasma, für MB/ Licht-behandeltes Plasma 89\%. Schlussfolgerung: Plasma, dass mit dem Theraflex MB Plasma System behandelt wurde, zeigte keinen profunden Einfluss der MB/Lichtbehandlung auf die Charakteristika der Thrombinbildung. In Übereinstimung mit Literaturdaten führte die MB/Licht-Behandlung zu einer Abnahme der Gerinnungsfaktoren V, VIII und XI. Die Abnahme betrug weniger als $20 \%$.

\begin{tabular}{ll}
\hline KARGER & @ 2009 S. Karger GmbH, Freiburg \\
Fax +497614520714 & $\begin{array}{l}\text { Accessible online at: } \\
\text { www.karger.com/tmh } \\
\text { Information@Karger.de } \\
\text { www.karger.com }\end{array}$ \\
\end{tabular}

\section{KARGER}




\section{Introduction}

Treatment of fresh frozen plasma (FFP) with methylene blue (MB) and light has been shown to effectively inactivate viruses and other pathogens. The method is highly efficient against enveloped viruses such as HIV, HBV, or West Nile virus [1-3]. Moreover, some (but not all) non-enveloped viruses and parasites [4] are inactivated.

$\mathrm{MB} /$ light-treated plasma (MB plasma) is in use in several different European countries. Mainly two different manufacturing procedures are applied, following either the original 'Springe Procedure' [1] or using the modified Theraflex ${ }^{\circledR}$ MB Plasma System [5]. The methods differ in the way MB is added to the plasma. While the 'Springe Procedure' uses an MB stock solution $(50 \mu \mathrm{mol} / \mathrm{l})$ the Theraflex System contains a dry MB pill $(85 \mu \mathrm{g} \mathrm{MB})$. The final concentration of $\mathrm{MB}$ is approximately $1 \mu \mathrm{mol} / \mathrm{l}$ for both methods. Furthermore, the 'Springe Procedure' includes an additional freeze-thaw step for cracking residual leukocytes to make intracellular viruses accessible to the action of MB and light. The Theraflex System on the other hand has an in-line $0.65 \mu \mathrm{m}$-membrane filter for the removal of remaining leukocytes (Plasmaflex ${ }^{\circledR}$ ). The Theraflex System additionally allows removal of MB and photoproducts after illumination by Blueflex ${ }^{\circledR}$ filtration [6].

Regardless of the manufacturing process, the inactivation procedure is associated with a moderate loss of coagulation factor activities: factor VIII (FVIII) and fibrinogen are decreased by up to $25 \%$ of their original activity [3]. Garwood et al. [6] have shown that, although a freeze-thaw step has little effect on fibrinogen and FVIII levels, losses due to MB treatment are $5-10 \%$ lower in fresh plasma compared to frozenthawed plasma. Other plasma factors like von WillebrandFactor, ADAMTS 13, AT, protein C and protein S, however, are only slightly or not at all affected [3,7-9]. The decrease in the level of fibrinogen is seen by the Clauss assay, but not in the antigen assay [9]. The reason is that MB/light treatment affects the biological activity of fibrinogen by photooxidizing histidine residues; this has, however, no influence on its concentration [10]. Together with a decrease in the activity of coagulation factors, an increase is seen in the coagulation time of global assays of coagulation like thrombin time (TT) or activated partial thromboplastin time (aPTT) [3].

Newly developed thrombin generation tests enable the continuous measurement of thrombin generation in plasma samples [11, 12]. Data on dynamic thrombin generation may be an indicator for the overall hemostatic potential of FFP [13]. However, until now there is only very limited data on the thrombin generation characteristics of plasma products like FFP. Recently Pock et al. [14] reported an impaired thrombin generation capacity in $\mathrm{MB} /$ light-treated plasma together with a profound increase in the global coagulation parameters (TT, reptilase time (RT)) and a reduced fibrinogen activity [15]. This prompted us to undertake a more detailed investigation especially on the quality and thrombin generation characteristics of MB plasma prepared with the Theraflex MB Plasma System. Results of thrombin generation were also compared with data obtained from solvent/ detergent(SD)-treated plasma.

\section{Material and Methods}

\section{Blood Collection and Processing}

Blood donations were obtained from unpaid voluntary donors who were screened according to the German guidelines [16]. Blood (500 ml) was collected into $70 \mathrm{ml}$ of CPD anticoagulant. After overnight storage at 4 ${ }^{\circ} \mathrm{C}$, plasma was separated by centrifugation (Hettich Roto Silenta, Tuttlingen, Germany) and subsequent processing with an automated blood component extractor (Optipress II; Baxter, Unterschleißheim, Germany). Plasma units (approximately 250-300 ml) were stored for a maximum of 2 $\mathrm{h}$ at room temperature until MB/light treatment.

\section{MB/light Treatment}

18 fresh plasma units of different blood groups (6 units each of the blood groups A, B, and O) were MB/light-treated using the Theraflex MB Plasma System (MacoPharma, Mouvaux, France). Before treatment a sample (referred to as 'untreated FFP') was taken from the bag to determine plasma parameters and thrombin generation. Plasma units were then connected to the Theraflex MB Plasma Bag System (MacoPharma) by sterile connecting device (TSCD; Terumo, Eschborn, Germany). Plasma was leukocyte-depleted by the integrated membrane filter (Plasmaflex; Macopharma) and then transferred to the illumination bag while dissolving the MB pill. Illumination was done on the Macotronic illumination device (MacoPharma) with a light dose of $180 \mathrm{~J} / \mathrm{cm}^{2}$. After illumination MB and photoproducts were removed by Blueflex (Macopharma) filtration. A sample for the determination of coagulation parameters and thrombin generation was taken from the freshly prepared plasma (referred to as 'MB plasma'). The inactivation procedure was finished within $24 \mathrm{~h}$ after donation. Plasma samples were frozen in liquid nitrogen immediately after sampling and stored at $-70{ }^{\circ} \mathrm{C}$ until determination of coagulation parameters and thrombin generation.

\section{SD Plasma}

SD plasma was commercially available plasma marketed in Germany (two units of each blood group). All batches of these units had passed the tests at the Paul Ehrlich Institute necessary for official batch release. Further data on clotting parameters have been published recently by SalgeBartels et al. [17]

\section{Determination of Coagulation Factors}

TT and fibrinogen activity according to Clauss were assayed using a BCS Analyser and reagents from Dade Behring, now Siemens Healthcare (Marburg, Germany).

Fibrinogen (Antigen) was determined by radial immunodiffusion using reagents from Dade Behring.

Clotting assays for factor V (FV), FVIII, and factor XI (FXI) were run using a coagulation analyzer (ACL 10000; IL, Milan, Italy). Measurements were done using deficient plasma from IL (FV and FXI) or Helena (FVIII).

RT [18] was determined using the Pefakit Reptilase time (Pentapharm, Basel, Switzerland) on a coagulation analyzer STA compact (Roche, Basel, Switzerland). An in-house plasma standard (calibrated against the WHO plasma standard for factor I) prepared from fresh frozen plasma served as a control. Functional protein $\mathrm{S}$ was measured using the Hemosil Pro S reagent kit (Instrumentation Laboratory, Kirchheim, Germany) on an ACL advanced coagulation analyzer (Instrumentation Laboratory). This assay is based on publications by Suzuki et al., 1988 [19] and Preda 
Table 1. The effect of MB treatment on factors of the coagulation system

\begin{tabular}{|c|c|c|c|c|c|c|c|}
\hline \multirow[t]{2}{*}{ Parameter } & \multirow[t]{2}{*}{$\begin{array}{l}\text { Reference } \\
\text { range }\end{array}$} & \multicolumn{2}{|c|}{$\begin{array}{l}\text { FFP before treatment } \\
(\mathrm{n}=18)\end{array}$} & \multicolumn{2}{|l|}{$\begin{array}{l}\text { MB plasma } \\
(\mathrm{n}=18)\end{array}$} & \multicolumn{2}{|c|}{ Percent decrease or increase } \\
\hline & & mean $\pm \mathrm{SD}$ & range & mean $\pm \mathrm{SD}$ & range & mean & range \\
\hline $\mathrm{TT}, \mathrm{s}$ & $16-21$ & $21.3 \pm 0.9$ & $19.7-22.9$ & $23.8 \pm 0.9^{*}$ & $22.3-25.1$ & +11.5 & $4.4-20.1$ \\
\hline $\mathrm{RT}, \mathrm{s}$ & $16-22$ & $18.5 \pm 1.9$ & $15.5-21.7$ & $20.9 \pm 2.4$ & $17.0-24.5$ & +12.7 & $-11.1-48.8$ \\
\hline Fibrinogen (Clauss), g/l & $1.8-4.5$ & $2.4 \pm 0.2$ & $1.8-3.0$ & $2.2 \pm 0.2 *$ & $1.7-2.8)$ & -6.9 & $-13.0-0.0$ \\
\hline Fibrinogen (Ag), g/l & $1.82-3.52$ & $2.80 \pm 0.6$ & $1.60-4.23$ & $2.83 \pm 0.6$ & $1.60-4.23$ & +1.0 & $-4.9-15.9$ \\
\hline $\mathrm{FV}, \%$ & $60-140$ & $123.6 \pm 23.6$ & $88-164$ & $112.8 \pm 21.3^{*}$ & $81-145$ & -8.8 & -13.5 to -6.2 \\
\hline FVIII, \% & $50-140$ & $87.0 \pm 23.0$ & $48-146$ & $76.8 \pm 24.1^{*}$ & $45-136$ & -11.7 & $-28.6-4.9$ \\
\hline FXI, \% & $65-150$ & $117.8 \pm 19.0$ & $85-150$ & $97.2 \pm 17.8^{*}$ & $71-135$ & -17.5 & -24.1 to -10.0 \\
\hline Protein S, \% & $67-132$ & $85.7 \pm 13.1$ & $60-116$ & $80.9 \pm 13.0^{*}$ & $56-108.5$ & -5.6 & -10.6 to -1.0 \\
\hline
\end{tabular}

* $\mathrm{p} \leq 0.001$ compared to untreated FFP (paired t-test).

et al., 1990 [20]. The first international standard for protein S plasma, human (WHO-93/590), served as the plasma standard while the control plasma was contained within the Hemosil Pro S kit.

\section{Thrombin Generation Assay}

Thrombin generation was assayed essentially as described previously [21]. Each determination was done in triplicate. $25 \mu \mathrm{l}$ plasma (normal plasma or sample) were distributed into wells of a microplate and supplemented with $25 \mu \mathrm{l}$ of a four-fold concentrated solution of reaction additives: $10 \mu \mathrm{l}$ tissue factor/phospholipids and $5 \mu \mathrm{l}$ Boc-Val-Arg-AMC were made up to $25 \mu \mathrm{l}$ with $\mathrm{HBS}(10 \mathrm{mmol} / \mathrm{l} \mathrm{Hepes,} 150 \mathrm{mmol} / \mathrm{l} \mathrm{NaCl}$; $\mathrm{pH} 7.4$ ) containing $1 \%$ human serum albumin. After 2 min prewarming, $50 \mu \mathrm{l}$ of a prewarmed solution of $20 \mathrm{mmol} / \mathrm{C} \mathrm{CaCl}_{2}$ in $\mathrm{HBS}$-containing albumin was added by the built-in dispenser, and readings were taken at $37^{\circ} \mathrm{C}$ every $20 \mathrm{~s}$ over $1 \mathrm{~h}$.

Normal plasma was obtained from Dade Behring. The thrombin substrate Boc-Val-Arg-AMC [22] was obtained from Bachem (Heidelberg, Germany). Innovin (tissue factor / phospholipids) was from DadeBehring. Cephalin (phospholipids) was from Roche-Boehringer (Mannheim, Germany). Innovin and cephalin were mixed 1/700 so as to yield a final concentration of $2 \mathrm{pmol} / \mathrm{l}$ tissue factor. The final concentration of thrombin substrate was $500 \mu \mathrm{mol} / \mathrm{l}$.

All other reagents were of the highest purity available from different sources.

The time needed to dispense the calcium solution and to mix the samples after dispensing was determined and taken into account (delay on the time axis).

The obtained data (thrombin peak, AUC, 'time to peak' (TTP)) are expressed as percent of normal plasma which was set as $100 \%$.

\section{Interference of $M B$ with the Thrombin Generation Assay}

One plasma unit was MB/light-treated using the Theraflex System. Samples were taken from the starting material, after addition of MB (MB concentration approximately $1 \mu \mathrm{mol} / \mathrm{l})$, and after illumination and removal of $\mathrm{MB}$ and photoproducts by Blueflex filtration. Thrombin generation was assayed according to the above-described method.

\section{Statistical Analysis}

Results of the plasma factor measurements are given as arithmetic mean \pm standard deviation (SD). For comparison of untreated with MB/lighttreated plasma the paired t-test was used. For comparison of SD plasma with untreated FFP and MB plasma the t-test was used. Differences were considered significant for $\mathrm{p} \leq 0.001$. Analysis was performed using commercially available software (Sigma Stat for Windows, Version 3.1, Systat Software, Erkrath, Germany).

\section{Results}

\section{Plasma Quality}

18 fresh plasma units of different blood groups were MB/lighttreated using the Theraflex MB Plasma System. Treatment included leukocyte depletion by Plasmaflex filtration, illumination on the Macotronic illumination device, and removal of MB and its photoproducts after illumination by Blueflex filtration. The results of the plasma factor measurements are given in table $1 . \mathrm{MB} /$ light treatment significantly affected different parameters: FV, FVIII and FXI were decreased by $9-18 \%$. Fibrinogen determined by Clauss method was lowered by $7 \%$ while the antigen level was not affected. Consequently TT and RT were prolonged (by about 12\%). Protein S was decreased by about $5 \%$.

\section{Thrombin Generation}

Thrombin generation in the plasma samples was measured after triggering coagulation by the addition of $\mathrm{CaCl}_{2}$ in the presence of phospholipids, tissue factor, and a fluorogenic thrombin substrate. Results are given in percent of normal plasma which was measured in parallel. Exemplary thrombograms from one set of samples, taken at different steps of the procedure, are shown in figure 1 . The assay was not affected by the presence of MB in the plasma. Values were comparable before and after the addition of MB.

The results of the thrombin generation assay are shown in table 2. The amount of free thrombin generated is given as AUC in percent of normal plasma. AUC was comparable for untreated (93\%), MB-treated (95\%) and SD-treated plasma $(107 \%)$. As untreated FFP and MB plasma are single donor products, the variations in AUC values are greater than for SD plasma which is a pooled product [23].

TTP value was determined to be $105 \%$ of normal plasma for untreated FFP, $89 \%$ for MB-treated, and 78\% for SDtreated plasma. MB treatment significantly shortened TTP by $15 \%$ ( $\mathrm{p} \leq 0.001)$. Compared with untreated plasma, TTP was also significantly decreased in SD plasma $(\mathrm{p} \leq 0.001)$. 


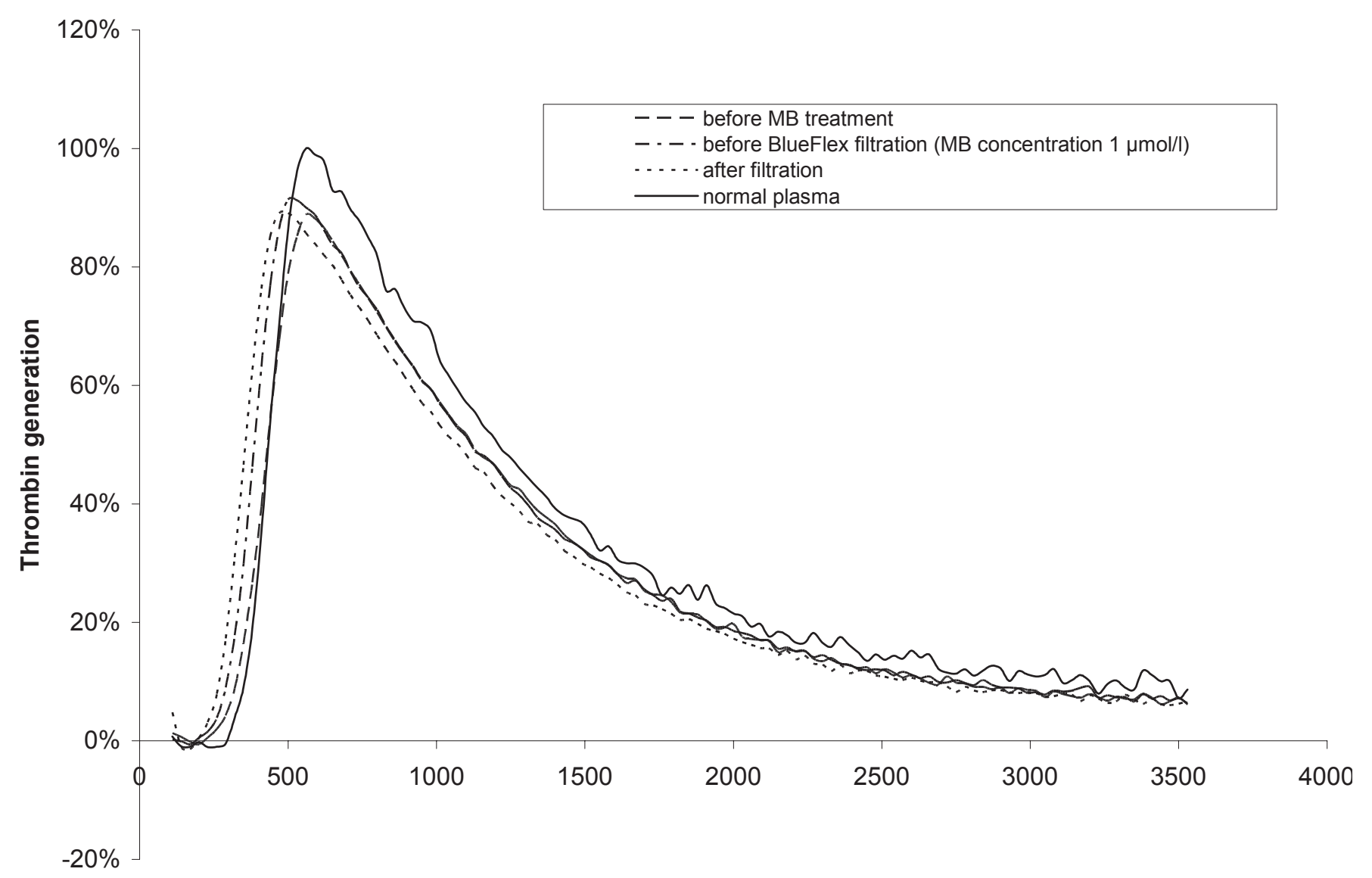

Time, s

Fig. 1. Typical thrombograms of plasma before and after MB treatment

Peak thrombin concentration ( $\%$ of normal plasma) ranged from 76 to $117 \%$, with a mean of $94 \%$ for untreated plasma. After MB/light treatment the concentration was increased non-significantly to a mean of $96 \%$ (range $78-124 \%$ ).

SD plasma had a peak thrombin concentration of $100 \%$ (97-105\%).

Similar to AUC, the variations in TTP and peak thrombin values were greater for untreated FFP and MB plasma than for SD plasma.

No correlation was found between single coagulation factors (FVIII, fibrinogen) or global tests (RT, TT) and thrombin generation parameters. This is in accordance with the fact that thrombin generation is not dependent on a single coagulation factor but on the interaction of the different factors of hemostasis.

\section{Discussion}

In the present report the quality and the thrombin generation capacity of MB plasma treated with the Theraflex MB plasma system were investigated.
As published by others [3, 6, 24, 25], some losses of the functional activities of the coagulation factors FI, FV, FVIII and FXI were found. However, the average loss did not exceed $20 \%$ for any of the investigated parameters.

It is known from the literature that MB/light treatment decreases the level of fibrinogen (Clauss), but not fibrinogen antigen $[9,26]$. In the present study fibrinogen measured by the Clauss method was significantly decreased by $7 \%$ while the antigen was not affected. This corresponds well with the prolonged RT and TT by about $12 \%$.

It is proposed that the oxidation of fibrinogen by $\mathrm{MB} /$ light treatment causes an inhibition of the polymerization of fibrin monomers [27]. The polymerization and gelation phases of fibrin are affected while the stabilization of the fibrin clot and fibrinolysis are not influenced [28]. Generation of a fibrin clot by conversion of fibrinogen to fibrin is thrombin-mediated [29]. Previous in vitro studies have demonstrated that the thrombin concentration present at the time of gelation influences fibrin clot structure [29]. Determination of thrombin generation might therefore be a valuable indicator for the hemostatic potential of plasma products. 
Table 2. Parameters of thrombin generation in FFP before and after MB treatment compared to SD plasma given in \% of normal plasma (mean $\pm \mathrm{SD}($ range $))$

\begin{tabular}{lcll}
\hline & $\begin{array}{l}\text { FFP before MB treatment } \\
(\mathrm{n}=18)\end{array}$ & $\begin{array}{l}\text { MB-treated plasma } \\
(\mathrm{n}=18)\end{array}$ & $\begin{array}{l}\text { SD plasma } \\
(\mathrm{n}=8)\end{array}$ \\
\hline AUC & $93 \pm 18(67-142)$ & $95 \pm 20(69-147)$ & $107 \pm 3(103-112)$ \\
TTP & $105 \pm 14(72-123)$ & $89 \pm 9 *(72-100)$ & $78.8 \pm 4^{\$}(72-82)$ \\
Peak thrombin & $94 \pm 11(76-117)$ & $96 \pm 12(78-124)$ & $100 \pm 3(97-105)$ \\
\hline${ }^{*} \mathrm{p} \leq 0.001$ compared to untreated FFP (paired t-test). \\
${ }^{\mathrm{p}} \leq 0.001$ compared to untreated FFP (t-test). \\
\hline
\end{tabular}

Thrombin generation was assayed using a test which monitors the formation of thrombin using a fluorogenic substrate for thrombin. The substrate itself however influences the thrombin generation [30]. To compensate for this effect, normal plasma was determined together with the samples, and results are expressed as percent of normal plasma, which was set as $100 \%$.

AUC, TTP and peak thrombin concentration were determined from the thrombogram. The total amount of thrombin generated, as given by the AUC, was comparable for untreated, MB-treated and SD plasma. According to the results obtained, the total capacity to generate thrombin is almost identical for the different plasma types tested.

The kinetics of thrombin formation are reflected by TTP and peak thrombin concentration. Our measurements showed a slight decrease of $15 \%$ in TTP after MB treatment. Remarkably, the time to peak for SD plasma was reduced by $18-28 \%$ compared with a pool of normal plasma. Differences between MB and SD plasma, however, should not be over-interpreted given the fact that the plasma originates from different starting material (pool vs. single donor units). The same holds true for the variations ('range') of different parameters. As untreated FFP and MB plasma are single donor products they show greater variations in AUC, TTP, and peak thrombin values compared to SD plasma which is a pool product. The mean peak thrombin concentrations, however, are comparable for the three plasma products investigated.

Our results are in striking contrast to those of Pock et al. [14] who reported a decrease of AUC by up to $60 \%$ for MB/ light-treated plasma compared with untreated FFP, while SD plasma showed values comparable with FFP. Similar discrepancies were shown for the kinetics of thrombin generation. They reported a prolonged lag phase and a decrease in peak thrombin concentration for MB plasma compared with FFP and SD plasma. There is no clear-cut explanation for the discrepancies between our results and those of Pock et al. [14]. Though different manufacturing processes are discussed in the latter report, the source of the MB plasma investigated is unknown. Furthermore, it is known that thrombin generation assays show a great variability depending on the reagents and assay conditions used [31]. The assays applied for analysis differ in various details. In our opinion an important difference is that the Technothrombin TGA used by Pock et al. [14] is based on the relatively efficient substrate Z-Gly-Gly-Arg-AMC [11] while Boc-Val-Arg-AMC was employed in the present inves- tigation. Using the latter substrate, a simplified calibration procedure can be used [12]. Although variations in assay design may yield different absolute values, this should not have a great impact on the overall results, given the fact that samples before and after $\mathrm{MB} /$ light treatment were determined using the same assay and resulted in minor changes only.

Suitable thrombin generation assays were developed only very recently. It is suggested that they should be used to determine states of bleeding disorders or thrombophilia and their treatment by antithrombotic or hemostatic medication [32]. The relevance of an impaired thrombin generation on the efficiency and safety of plasma products is unclear. While classical quality parameters like FVIII are based on the determination of a single coagulation factor only, thrombin generation assays might be a valuable indicator for the overall hemostatic potential of FFP. However, to date there is only very limited data on thrombin generation in FFP [13, 14]. Lawrie et al. [13] assessed thrombin generation in FFP prepared under different conditions. Also Pock et al. [14] determined thrombin generation parameters in FFP. Data was determined using two different measurement systems, and results are not comparable between the two studies. Further investigations are necessary to standardize measurements of thrombin generation [31] and to establish a threshold for maximum and minimum thrombin generation for therapeutic plasma products.

The results of the present investigation suggest that there are no profound differences in the characteristics of thrombin generation for MB plasma, SD-treated plasma, and untreated plasma. Variations are within the normal range for single donor units. Thus, it can be concluded that the quality and thrombin generation capacity of FFP treated with MB/light are well preserved.

\section{Acknowledgement}

We would like to express our gratitude to Dr. F. Bergmann from the 'Ärztliche Partnerschaft Wagner/Stibbe' in Hanover, Germany, for performing factor determinations and R. Nawrot for help with RT and protein $\mathrm{S}$ determinations. The support of A. Wenk and J. Linneweber in preparing the manuscript is acknowledged.

\section{Disclosure}

The authors declared no conflict of interest. 


\section{References}

1 Mohr H, Lambrecht B, Selz A: Photodynamic virus inactivation of blood components. Immunol Invest 1995;24:73-85.

2 Mohr H, Knuver-Hopf J, Gravemann U, RedeckerKlein A, Muller TH: West Nile virus in plasma is highly sensitive to methylene blue-light treatment. Transfusion 2004;44:886-890.

$\checkmark 3$ Williamson LM, Cardigan R, Prowse CV: Methylene blue-treated fresh-frozen plasma: what is its contribution to blood safety? Transfusion 2003;43: 1322-1329.

4 Girones N, Bueno JL, Carrion J, Fresno M, Castro E: The efficacy of photochemical treatmen with methylene blue and light for the reduction of Trypanosoma cruzi in infected plasma. Vox Sang 2006;91:285-291.

5 Hornsey VS, Drummond O, Young D, Docherty A, Prowse CV: A potentially improved approach to methylene blue virus inactivation of plasma: The maco pharma maco-tronic system. Transfus Med 2001;11:31-36.

6 Garwood M, Cardigan RA, Drummond O, Hornsey V, Turner CP, Young D, Williamson LM, Prowse CV: The effect of methylene blue photoinactivation and methylene blue removal on the quality of fresh-frozen plasma. Transfusion 2003;43: 1238-1247.

7 Yarranton H, Lawrie AS, Purdy G, Mackie IJ, Machin SJ: Comparison of von Willebrand factor antigen, von Willebrand factor-cleaving protease and protein $\mathrm{s}$ in blood components used for treatment of thrombotic thrombocytopenic purpura. Transfus Med 2004;14:39-44.

8 Cardigan R, Allford S, Williamson L: Levels of von Willebrand factor-cleaving protease are normal in methylene blue-treated fresh-frozen plasma. Br J Haematol 2002;117:253-254.

$\checkmark 9$ Zeiler T, Riess H, Wittmann G, Hintz G, Zimmermann R, Muller C, Heuft HG, Huhn D: The effect of methylene blue phototreatment on plasma proteins and in vitro coagulation capability of single-donor fresh-frozen plasma. Transfusion 1994;34:685-689.

10 Henschen-Edman AH: Photo-oxidation of histidine as a probe for aminoterminal conformational changes during fibrinogen-fibrin conversion. Cell Mol Life Sci 1997;53:29-33.

-11 Hemker HC, Giesen P, Al Dieri R, Regnault V, de Smed E, Wagenvoord R, Lecompte T, Beguin S The calibrated automated thrombogram (cat): A universal routine test for hyper- and hypocoagulability. Pathophysiol Haemost Thromb 2002;32: 249-253.
12 Tapp HJ, Grundmann C, Kusch M, Koenig H: Thrombin generation assay based on a certain substrate allows a simplified calibration procedure. Hämostaseologie 2008;28:A65.

13 Lawrie AS, Cardigan RA, Williamson LM, Machin SJ, Mackie IJ: The dynamics of clot formation in fresh-frozen plasma. Vox Sang 2008;94:306-314

14 Pock K, Heger A, Janisch S, Svae TE, Romisch J: Thrombin generation capacity is impaired in methylene-blue treated plasma compared to normal levels in single-donor fresh-frozen plasma, a licensed solvent/detergent-treated plasma (Octaplas ${ }^{\circledR}$ ) and a development product (Uniplas ${ }^{\circledR}$ ). Transfus Apher Sci 2007;37:223-231.

15 Heger A, Romisch J, Svae TE: A biochemical comparison of a pharmaceutically licensed coagulation active plasma (Octaplas) with a universally applicable development product (Uniplas) and single-donor FFPs subjected to methylene-blue dye and white-light treatment. Transfus Apher Sci 2006;35:223-233.

16 Paul-Ehrlich-Institut, Bundesärztekammer: Richtlinie zur Gewinnung von Blut und Blutbestandteilen und zur Anwenduung von Blutprodukten (Haemotherapie). Köln, Deutscher Ärzte-Verlag, 2001.

17 Salge-Bartels U, Breitner-Ruddock S, Hunfeld A, Seitz R, Heiden M: Are quality differences responsible for different adverse reactions reported for SD-plasma from USA and Europe? Transfus Med 2006;16:266-275.

18 Funk C, Gmur J, Herold R, Straub PW: Reptilase- a new reagent in blood coagulation. Br J Haematol 1971;21:43-52.

19 Suzuki K, Nishioka J: Plasma protein s activity measured using Protac, a snake venom derived activator of protein C. Thromb Res 1988;49:241-251.

20 Preda L, Tripodi A, Valsecchi C, Lombardi A, Finotto E, Mannucci PM: A prothrombin timebased functional assay of protein S. Thromb Res 1990;60:19-32.

21 Dusel CH, Grundmann C, Eich S, Seitz R, Konig $\mathrm{H}$ : Identification of prothrombin as a major thrombogenic agent in prothrombin complex concentrates. Blood Coagul Fibrinolysis 2004;15:405-411.

22 Kawabata S, Miura T, Morita T, Kato H, Fujikawa K, Iwanaga S, Takada K, Kimura T, Sakakibara S: Highly sensitive peptide-4-methylcoumaryl-7amide substrates for blood-clotting proteases and trypsin. Eur J Biochem 1988;172:17-25.
23 Hellstern P, Sachse H, Schwinn H, Oberfrank K: Manufacture and in vitro characterization of a solvent/detergent-treated human plasma. Vox Sang 1992;63:178-185.

24 Politis C, Kavallierou L, Hantziara S, Katsea P, Triantaphylou V, Richardson C, Tsoutsos D, Anagnostopoulos N, Gorgolidis G, Ziroyannis P: Quality and safety of fresh-frozen plasma inactivated and leucoreduced with the theraflex methylene blue system including the blueflex filter: 5 years' experience. Vox Sang 2007;92:319-326.

25 Osselaer JC, Debry C, Goffaux M, Pineau J, Calomme G, Dubuc E, Chatelain B, Vandendaele MC, Hsu J, Rheinschmidt M, Lin L: Coagulation function in fresh-frozen plasma prepared with two photochemical treatment methods: methylene blue and amotosalen. Transfusion 2008;48:108-117.

26 Depasse F, Sensebe L, Seghatchian J, Andreu G, Samama MM: The influence of methylene blue light treatment and methylene blue removal filter on fibrinogen activity states and fibrin polymerisation indices. Transfus Apher Sci 2005;33:63-69.

27 Inada Y, Hessel B, Blomback B: Photooxidation of fibrinogen in the presence of methylene blue and its effect on polymerization. Biochim Biophys Acta 1978;532:161-170.

28 Suontaka AM, Blomback M, Chapman J: Changes in functional activities of plasma fibrinogen after treatment with methylene blue and red light. Transfusion 2003;43:568-575.

29 Wolberg AS: Thrombin generation and fibrin clot structure. Blood Rev 2007;21:131-142.

30 Butenas S, Mann KG: Caution in the interpretation of continuous thrombin generation assays. J Thromb Haemost 2007;5:1084-1085; author reply 1085-1087.

31 Dargaud Y, Luddington R, Gray E, Negrier C, Lecompte T, Petros S, Hogwood J, Bordet JC, Regnault V, Siegemund A, Baglin T: Effect of standardization and normalization on imprecision of calibrated automated thrombography: an international multicentre study. $\mathrm{Br} \mathrm{J}$ Haematol 2007;139:303-309.

32 Hemker HC, Al Dieri R, De Smedt E, Beguin S: Thrombin generation, a function test of the haemostatic-thrombotic system. Thromb Haemost 2006; 96:553-561. 